\title{
Analisis Penerapan Multi Akad Pada Pembiayaan ARRUM (Ar-Rahn Untuk Usaha Mikro) Di PT. Pegadaian (Persero) Syariah Taba Cemekeh Kota Lubuklinggau.
}

\author{
Oleh \\ Ikit dan Ade Lawren Oktavia
}

\begin{abstract}
Abstrak
Pegadaian Syariah mempunyai produk-produk utama untuk menyalurkan dananya kepada masyarakat. Produk-produk tersebut yaitu Rahn, Arrum, mulia, dan lain-lain. Produk Arrum adalah skim pinjaman dengan sistem syariah bagi para pengusaha mikro dan kecil untuk keperluan pengembangan usaha dengan sistem pengembalian secara angsuran, mengunakan jaminan BPKB mobil atau motor. Produk Arrum tersebut berjalan di atas dua akad transaksi syariah yaitu akad rahn dan akad ijarah. Hasil penelitian menyatakan bahwa transaksi multi akad pada dasarnya berkaitan erat dengan syarat dan akad yang disertakan di dalam transaksi tersebut, maka kesahihan setiap transaksi multi akad akan bergantung pada sahih tidaknya syarat dan akad yang disertakan dengannya. Jika syarat dan akad yang ada di dalam transaksi itu sah secara syariat maka transaksi multi akad tersebut dapat dikatakan sah secara syariat, namun jika syarat dan akad yang terdapat di dalamnya itu tidak sah secara syariat maka transaksi itu pun tidak bisa dikatakan sah.
\end{abstract}

\section{Kata Kunci: Pegadaian dan Pembiayaan ARRUM}

\section{A. Pendahuluan}

Berbicara masalah pinjam-meminjam ini, Islam telah membolehkannya, baik melalui individu maupun suatu lembaga keuangan seperti bank, asuransi, pegadaian, dan lainnya. Namun tidak di benarkan untuk meminta kelebihan dari pokok pinjaman dengan bentuk bunga karena riba. Dalam perspektif ekonomi, pegadaian merupakan salah satu alternatif pendanaan yang sangat efektif karena tidak memerlukan proses dan persyaratan yang rumit. Dalam bentuk pendanaan ini sudah ada lama dan sudah dikenal masyarakat Indonesia yang secara resmi mempunyai izin melaksanakan kegiatan lembaga keuangan berupa pembiayaan dalam bentuk penyaluran dana kemasyarakat atas dasar hukum gadai.

Gadai yang terungkap dalam Pasal 1150 Kitab Undang-UndangHukum Perdata adalah suatu hak yang diperoleh seseorang yang mempunyai piutang atas suatu barang bergerak, yaitu barang bergerak tersebut diserahkan kepada orang 
yang berpiutang oleh orang yang mempunyai utang atau orang lain atas nama orang yang mempunyai utang. Karena itu, makna gadai dalam bahasa hukum perundang-undangan disebut sebagai barang jaminan, agunan, dan rungguhan. ${ }^{1}$

Perum pegadaian merupakan Badan Usaha Milik Negara (BUMN) yang bergerak di bidang jasa keuangan Bukan Bank dengan kegiatan usaha utamanya menyalurkan pinjaman kepada masyarakat berdasarkan hukum gadai, fidusia, dan usaha lainya yang menguntungkan. Dari pengalaman melayani pinjaman masyarakat golongan kebawah ini, ada suatu kebutuhan dari para pengguna jasa pegadaian dari kalangan usaha mikro kecil yang mengharapkan tetap bisa menggunakan anggunan kendaraan bermotor miliknya untuk menunjang kegiatan operasional usahanya. Hal ini memicu pegadaian syariah untuk bisa merespon kebutuhan masyarakat tersebut.

Pegadaian Syariah mempunyai produk-produk utama untuk menyalurkan dananya kepada masyarakat. Produk-produk tersebut yaitu Rahn, Arrum, mulia, dan lain-lain. Produk Arrum adalah skim pinjaman dengan sistem syariah bagi para pengusaha mikro dan kecil untuk keperluan pengembangan usaha dengan sistem pengembalian secara angsuran, mengunakan jaminan BPKB mobil atau motor. Produk Arrum tersebut berjalan di atas dua akad transaksi syariah yaitu akad rahn dan akad ijarah.

Sebagian masyarakat menganggap pegadaian hanya menyediakan akad gadai. Dengan ilustrasi mereka datang ke pegadaian, menggadaikan barang jaminan lalu mereka akan mendapatkan uang dari barang yang mereka gadaikan. Tetapi pada kenyataanya, pegadaian menyediakan banyak produk selain akad gadai itu sendiri. Jika masyarakat ditanya mengenai apa yang mereka ketahui mengenai Pegadaian Syariah, maka jawabannya adalah gadai. Selain itu, mereka juga menyatakan bahwa gadai di pegadaian konvensional sama karena dipungut tambahan dimana pada pegadaian konvensional disebut dengan bunga, sedangkan di Pegadaian Syariah disebut dengan ujroh.

Karena produk Arrum adalah produk baru, maka penulis merasa perlu mencari informasi kepada pihak pengelola Pegadaian Syariah Taba Cemekeh

${ }^{1}$ Zainudin Ali, Hukum Gadai Syariah, (Jakarta: Sinar Grafika,2016),h. 2. 
Kota Lubuklinggau mengenai penerapan akad yang di lakukan pada pembiayaan Arrum. Dari hasil wawancara dan informasi yang didapat tersebut maka penulis menemukan bahwa pembiayaan Arrum adalah penyaluran pinjaman kepada pengusaha mikro untuk tambahan modal usaha yang menggunakan penerapan pola akad Rahn dan akad Ijarah dengan barang jaminan BPKB kendaraan Bermotor atau mobil, memiliki usaha minimal 1 (satu) tahun telah berjalan dan berdasarkan survei kelayakan usaha, Berbeda pada produk lainnya yang menggunakan barang riil sebagai agunan atas jaminan pembiayaan atau pinjaman utang seperti barang perhiasan emas, kendaraan bermotor, barang elektronik hp, laptop dan lainnya.

Pada dasarnya ketentuan atas isi perjanjian atau Akad Pembiayaan Arrum dibuat oleh pegadaian syariah, yang mana pada saat melakukan transaksi nasabah harusnya terlebih dahulu memahami isi dan maksud dari isi akad, dan nasabah perlu mengetahui penerapan akad apa saja yang di gunakan. Kebanyakan dari nasabah yang melakukan transaksi tidak sepenuhnya memahami isi dan maksud akad perjanjian pembiayaan Arrum, sehingga masyarakat cenderung tidak mengerti dan langsung menandatangani akad tersebut. Nasabah yang cenderung pasif tidak akan bertanya tentang penggunaan akad, sehingga nasabah hanya mengetahui jumlah pinjaman dan angsuran kewajiban tiap bulan yang harus mereka penuhi. Berkaitan dengan hal di atas maka penulis tertarik untuk melakukan penelitian pada PT. Pegadaian (Persero) Syariah Taba Cemekeh Kota Lubuklinggau dengan mengangkat suatu judul “Analisis Penerapan Multi Akad Pada Pembiayaan ARRUM (Ar-Rahn Untuk Usaha Mikro) Di PT. Pegadaian (Persero) Syariah Taba Cemekeh Kota Lubuklinggau."

\section{B. Rumusan Masalah}

Dari latar belakang yang telah diuraikan, maka rumusan masalah dalam penelitian ini adalah:

1. Bagaimana mekanisme operasional pembiayaan ARRUM di PT. Pegadaian (persero) Syariah Taba Cemekeh Kota Lubuklinggau? 
2. Bagaimana Penerapan Transaksi Multi Akad Pada Pembiayaan ARRUM di PT. Pegadaian (persero) Syariah Taba Cemekeh Kota Lubuklinggau?

\section{Kerangka Teoritik}

Menurut Az-Zarqa menyatakan bahwa dalam pandangan syar'a, suatu akad merupakan ikatan secara hukum yang dilakukan oleh dua atau beberapa pihak yang sama-sama berkeinginan untuk mengikatkan diri. Kehendak atau keinginan pihak-pihak yang mengikatkan diri itu sifatnya tersembunyi dalam hati. Oleh sebab itu, untuk menyatakan kehendak masing-masing harus di ungkapkan dalam suatu pernyataan. Pernyataan pihak-pihak yang berakad itu disebut ijab dan qabul. Ijab adalah pernyataan pertama yang dikemukakan oleh salah satu pihak, yang mengandung keinginannya secara pasti untuk mengikat diri. Sedangkan, qabul adalah pernyataan pihak lain setelah ijab yang menunjukkan persetujuannya untuk mengikatkan diri. ${ }^{2}$ Sedangkan pengertian perjanjian menurut subekti adalah "suatu peristiwa di mana seorang berjanji kepada seorang lain atau di mana dua orang itu saling berjanji untuk melaksanakan sesuatu hal."”3

Gadai adalah suatu hak yang diperoleh seseorang yang berpiutang atas suatu barang bergerak, yang diserahkan kepadanya oleh seseorang yang berutang atau oleh seseorang lain atas namanya, dan yang memberikan kekuasaan kepada orang berpiutang lainnya: dengan pengecualian biaya untuk melelang barang tersebut dan biaya yang telah dikeluarkan untuk menyelamatkannya setelah barang itu digadaikan, biaya-biaya mana harus didahulukan (Kitab UU Hukum Perdata Pasal $1150) .^{4}$

Pengertian gadai (rahn) secara bahasa adalah tetap, kekal, dan jaminan. Sedangkan dalam pengertian istilah adalah menyandera sejumlah harta yang diserahkan sebagai jaminan secara hak, dan dapat diambil kembali sejumlah harta dimaksud sesudah ditebus. ${ }^{5}$ Menurut kamus besar Bahasa Indonesia, gadai merupakan:

\footnotetext{
${ }^{2}$ Muhammad Syakir Sula, Asuransi Syariah (Life and General): Konsep dan Sistem Operasional, (Jakarta: Gema Insani Press, 2004), h. 39.

${ }^{3}$ Gemala Dewi dkk, Hukum Perikatan Islam di Indonesia, (Jakarta: Kencana, 2005), h. 47.

${ }^{4}$ Julius R. Latumaerissa, Bank dan Lembaga Keuangan Lain, (Jakarta: Salemba Empat, 2011), h. 460.

${ }^{5}$ Zainudin Ali, Hukum Gadai Syariah ..., h. 1.
} 
1. Meminjam uang dalam batas waktu tertentu dengan menyerahkan barang sebagai tanggungan, jika telah sampai waktunya tidak ditebus, barang itu menjadi hak yang memberi pinjaman.

2. Barang yang diserahkan sebagai tanggunan hutang.

3. Kredit jangka pendek dengan jaminan yang berlaku 3 (tiga) bulan setiap kali dapat diperpanjang apabila tidak dihentikan oleh salah satu pihak yang bersangkutan. ${ }^{6}$

Selain pengertian gadai yang dikemukakan di atas, para ahli hukum Islam juga mengungkapkan pengertian gadai sebagai berikut: ${ }^{7}$

a. Ulama Syafi'iyah mendefinisikan “menjadikan suatu barang yang biasa dijual sebagai jaminan utang dipenuhi dari harganyaa, bila yang berutang tidak sanggup membayar utangnya".

b. Ulama Hanabillah mengungkapkan "suatu benda yang dijadikan kepercayaan suatu utang, untuk dipenuhi dari harganya, bila yang berutang tidak sanggup membayar utangnya”.

c. Ulama Malikiyah mendefinisikan "sesuatu yang bernilai harta (mutamawwal) yang diambil dari pemiliknya untuk dijadikan pengikat atas utang yang tetap (mengikat).

d. Ahmad Azhar Basyir, Rahn adalah perjanjian menahan sesuatu barang sebagai tanggungan utang atau menjadikan sesuatu benda bernilai menurut pandangan syara' sebagai tanggungan marhun bih, sehingga dengan adanya tanggungan utang itu seluruh atau sebagian utang dapat diterima.

e. Muhammad Syafi'I Antonio, gadai syariah ( $r a h n$ ) adalah menahan salah satu harta milik nasabah sebagai barang jaminan (marhun) atas utang atau pinjaman (marhun bih) yang diterimanya. Marhun tersebut memiliki nilai ekonomis. Dengan demikian, pihak yang menahan atau penerima gadai memperoleh jaminan untuk dapat mengambil kembali seluruh atau sebagian piutangnya.

\footnotetext{
${ }^{6}$ Hasan Alwi, Kamus Besar Bahasa Indonesia, (Jakarta: Balai Pustaka, 1919), h. 325.

${ }^{7}$ Zainudin Ali, Hukum Gadai..., h. 2-3.
} 
Secara umum usaha gadai adalah kegiatan menjaminkan barang-barang yang berharga kepada pihak tertentu, guna memperoleh sejumlah uang dan barang yang dijaminkan akan ditebus kembali sesuai dengan perjanjian antara nasabah dengan lembaga gadai. ${ }^{8}$

Dasar hukum yang menjadi landasan gadai syariah adalah ayat-ayat $\mathrm{Al}$ Qur'an, Hadits Nabi Muhammad saw., Ijma' ulama, dan Fatwa MUI. Hal dimaksud, diungkapkan sebagai berikut. Dalam $Q S$. Al-Baqarah ayat 283 yang diguakan sebagai dasar dalam membangun konsep gadai adalah sebagai berikut, yang artinya:"Jika kamu dalam perjalanan (dan bermu'amalah tidak secara tunai) sedang kamu tidak memperoleh seorang penulis, maka hendaklah ada barang tanggungan yang dipegang (oleh yang berpiutang). Akan tetapi jika sebagian kaтu mempercayai sebagian yang lain, maka hendaklah yang dipercayai itu menunaikan amanatnya (hutangnya) dan hendaklah ia bertakwa kepada Allah Tuhannya; dan janganlah kamu (para saksi) menyembunyikan persaksian. Dan barangsiapa yang menyembunyikannya, maka sesungguhnya ia adalah orang yang berdosa hatinya; dan Allah Maha Mengetahui apa yang kamu kerjakan."

Syaikh Muhammad' Ali As-Syais berpendapat, bahwa ayat Al-Qur'an di atas adalah petunjuk untuk menerapkan prinsip kehati-hatian bila seseorang hendak melakukan transaksi utang-piutang yang memakai jangka waktu dengan orang lain, dengan cara menjaminkan sebuah barang kepada orang yang berpiutang (rahn). ${ }^{9}$

Dasar hukum yang kedua untuk dijadikan rujukan dalam membuat rumusan gadai syariah adalah Nabi Muhammad saw, yang antara lain diungkapkan sebagai berikut: Artinya:"Telah meriwayatkan kepada kami Ishaq bin Ibrahim AlHanzhali dan Ali bin Khasyram berkata: keduanya mengabarkan kepada kami Isa bin Yunus bin 'Amasy dari Ibrahim dari Aswad dari 'Aisyah berkata: bahwasanya Rasulullah saw, membeli makanan dari seorang Yahudi dengan menggadaikan baju besinya”. (HR. Muslim) dan Hadits dari Anas bin Malik ra,

\footnotetext{
${ }^{8}$ Kasmir, Bank dan Lembaga Keuangan ..., h. 233.

${ }^{9}$ Zainudin Ali, Hukum Gadai Syariah..., h. 5.
} 
yang diriwayatkan oleh Ibnu Majah yang berbunyi: "Telah meriwayatkan kepada kami Nashr bin Ali Al-Jahdhami, ayahku telah meriwayatkan kepadaku, meriwayatkan kepada kami Hisyam bin Qatadah dari anas berkata: Sungguh Rasulullah saw, menggadaikan baju besinya kepada seorang Yahudi di Madinah dan menukarnya dengan gandum untuk keluarganya”. (HR. Ibnu Majah).

Hadits dari Abu Hurairah yang diriwayatkan oleh Imam Al-Bukhari, yang Artinya:"Telah meriwayatkan kepada kami Muhammad bin Muqatil, mengabarkan kepada kami Abdullah bin Mubarak, mengabarkan kepada kami Zakariyya dari Sya'bi dari Abu Hurairah, dari Nabi saw., bahwasanyabeliau bersabda: Kendaraan dapat digunakan dan hewan ternak dapat pula diambil manfaatnya apabila digadaikan penggadai wajib memberikan nafkah dan penerima gadai boleh mendapatkan manfaat”. (HR. Al-Bukhari). Hadits riwayat Abu Hurairah ra., yang Artinya: "Barang gadai tidak boleh disembunyikan dari pemilik yang menggadaikan, baginya risiko dan hasilnya." (HR. Asy-Syafi'I dan Ad-Daruquthni). ${ }^{10}$

Ijma 'Ulama, Jumhur ulama menyepakati kebolehan status hukum gadai. Hal dimaksud, berdasarkan pada kisah Nabi Muhammad saw, yang menggadaikan baju besinya untuk mendapatkan makanan dari seorang Yahudi. Para ulama juga mengambil indikasi dari contoh Nabi Muhammad saw, tersebut, ketika beliau beralih dari yang biasanya bertransaksi kepada para sahabat yang kaya kepada seorang Yahudi, bahwa hal itu tidak lebih sebagai sikap Nabi Muhammad saw, yang tidak mau memberatkan para sahabat yang biasanya enggan mengambil ganti ataupun harga yang diberikan oleh Nabi Muhammad saw kepada mereka.

Fatwa Dewan Syariah Nasional Majelis Ulama Indonesia (DSN-MUI) menjadi salah satu rujukan yang berkenaan gadai syariah, diantaranya dikemukakan sebagai berikut: Fatwa Dewan Syariah Nasional Majelis Ulama Indonesia No: 25/DSN-MUI/III/2002, tentang Rahn. Dan Fatwa Dewan Syariah Nasional Majelis Ulama Indonesia No: 26/DSN-MUI/III/2002, tentang Rahn Emas.

${ }^{10}$ Zainudin Ali, Hukum Gadai Syariah ..., h. 6-8 


\section{Metode Penelitian}

a. Jenis Penelitian

Jenis penelitian ini menggunakan penelitian lapangan (field research) dengan pendekatan kualitatif. Dalam hal ini penulis menekankan pada penelitian lapangan atau field research yang bersifat “deskriptif analitik"yang menggunakan pendekatan kualitatif yaitu uraian naratif suatu proses tingkah laku subjek yang sesuai dengan masalah yang diteliti. ${ }^{11}$ Deskriptif kualitatif yaitu penelitian yang berusaha menggambarkan, menguraikan dan menjelaskan mengenai, mengamati, mencatat serta mengumpulkan berbagai data dan informasi yang diperoleh di lapangan mengenai penerapan multi akad dalam pembiayaan ARRUM (Ar-Rahn usaha untuk mikro) PT. Pegadaian (persero) Syariah Taba Cemekeh Kota Lubuklinggau

b. Subjek Penelitian

Adapun yang menjadi subjek atau sumber informasi dalam penelitian ini adalah nasabah PT. Pegadaian (persero) Syariah Taba Cemekeh Kota Lubuklinggau.

c. Teknik Pengumpulan Data

Pengumpulan data melalui cara diantaranya:

a. Observasi yaitu informasi tertentu yang diperoleh dengan baik melalui pengamatan langsung dilapangan oleh peneliti. ${ }^{12}$ Memperoleh data berupa pengamatan langsung di tempat penelitian untuk memperoleh data secara nyata mengenai pembiayaan yang ada di PT. Pegadaian (persero) Syariah Taba Cemekeh Kota Lubuklinggau. Selain itu metode ini digunakan untuk melihat profil pegadaian syariah yang meliputi visi dan misi pegadaian syariah kota lubuklinggau.

b. Wawancara yaitu pengumpulan data dengan tanya jawab dan dikerjakan secara sistematis dan berdasarkan pada tujuan penyelidikanya. ${ }^{13}$ Dalam

${ }^{11}$ Amirudin Hadi dan Haryono, Metodologi Penelitian Pendidikan, (Jakarta: Pustaka Setia, 1998), h. 17.

${ }^{12}$ Sanapiah Faisal, Format-Format Penelitan Sosial, (Jakarta: PT Raja Grafindo Persada, 1995), h.22.

${ }^{13}$ Sutrisnohadi, Metodologi Research, (Yogyakarta: Yayasan Penerbit Fakultas psikologi, 1990), h.183. 
hal ini penulis melakukan wawancara secara langsung (Interview) untuk mendapatkan data-data mengenai penerapan multi akad dalam pembiayaan ARRUM (Ar-Rahn untuk usaha mikro) di PT. Pegadaian (persero) Syariah Taba Cemekeh Kota Lubuklinggau peneliti menyampaikan beberapa pertanyaan kepada responden untuk dijawab dengan jelas dan lengkap.

c. Dokumentasi adalah penelitian yang dilakukan terhadap informasi yang didokumentasikan dengan gambar, tulisan dan lain- lain. ${ }^{14}$ Sumber data yang akan diperoleh melalui dokumentasi akan diperoleh melalui bukubuku, foto-foto, riset yang telah dilakukan sebelumnya mengenai atau berkaitan dengan objek penelitian, serta data-data lainnya yang berkaitan dengan objek penelitian. Metode ini penulis gunakan untuk mendapatkan data mengenai: profil pegadaian syariah, sejarah berdirinya pegadaian syariah, visi dan misi pegadaian syariah.

\section{E. Hasil Penelitian}

Berdasarkan hasil penelitian yang penulis lakukan dan telah dikemukakan dalam penyajian data, maka dianalisis data yang menjadi pokok pembahasan adalah menjawab rumusan masalah dan dari data yang digali dalam penelitian ini diuraikan sebagai berikut:

\section{Mekanisme Operasional Pembiayaan ARRUM (Ar-Rahn Untuk Usaha Mikro) di PT. Pegadaian (persero) Syariah Taba Cemekeh Kota Lubuklinggau}

Menurut Muhammad didalam bukunya Edi Susilo pembiayaan secara luasberarti financial atau pembelanjaan, yaitu pendanaan yang dikeluarkan untuk mendukung investasi yang telah direncanakan, baik dilakukan sendiri maupun dijalankan oleh orang lain. Sedangkan, dalam arti sempit pembiayaan dipakai untuk mendifinisikan pendanaan yang dilakukan oleh lembaga pembiayaan seperti bank syariah kepada nasabah. ${ }^{15}$

\footnotetext{
${ }^{14}$ Husein Umar, Research Methold Financeand Banker, (Jakarta: PT Remaja, 2002), h. 149.

${ }^{15}$ Edi Susilo, Analisis Pembiayaan dan Risiko Perbankan Syariah..., h. 109.
} 
Pembiayaan Arrum merupakan pendanaan yang diberikan oleh pihak pegadaian syariah kepada nasabah dengan menggunakan akad rahn (gadai) dengan menggunakan jaminan barang yang memiliki nilai dan kegunaan. Produk ARRUM BPKB adalah produk khusus yang ditujukan kepadapara pengusaha mikro sebagai tambahan modal usaha dengan jaminan berupa BPKB (Bukti

Pemilikan Kendaraan Bermotor) mobil atau sepeda motor yang mana barang masih bisa dimanfaatkan oleh nasabah. Transaksi pembiayaan ARRUM BPKB di

Kantor Cabang Pegadaian Syariah Lubuklinggau menggunakan akad ar-rahn dengan jaminan BPKB kendaraan bermotor baik berupa mobil atau sepeda motor.

Mekanisme pembiayaan ARRUM BPKB di Pegadaian Syariah Kantor Cabang

Lubuklinggau yaitu nasabah datang ke pegadaian syariah untuk mengajukan pembiayaan ARRUM BPKB dengan membawa jaminan berupa BPKB kendaraan bermotor dengan menggunakan akad ar-rahn, dari pembiayaan ini calon nasabah memperoleh pinjaman dengan cara menggadaikan BPKB dan mendapatkan tambahan modal bisa mencapai $70 \%$ dari nilai taksiran yang ditentukan.

Setelah nasabah memenuhi persyaratan yang diminta, selanjutnya adalah proses peninjauan lokasi usaha, apakah layak memperoleh pembiayaan atau tidak, sesuai dengan kriteria yang ditetapkan divisi usaha mikro kantor cabang pegadaian syariah Lubuklinggau. Proses ini dilakukan paling lambat dua hari setelah proses pengajuan pembiayaan.

Dengan pembiayaan ini pengusaha dapat memperoleh tambahan modal dengan proses yang cepat dan mudah, pencairan dana dapat dilakukan paling cepat dalam 3 hari dan paling lambat satu minggu setelah pengajuan. Produk ARRUM BPKB di Pegadaian Syariah Kantor Cabang Lubuklinggau merupakan salah satu produk yang membantu para pengusaha kecil untuk memperoleh tambahan modal usaha karena produk ini memberikan pinjaman mulai Rp 3.000.000 yang sesuai dengan kebutuhan para pengusaha kecil yang tidak memiliki jaminan dengan nilai taksiran yang tinggi.

2. Penerapan Transaksi Multi Akad Pada Pembiayaan ARRUM (Ar-Rahn Untuk Usaha Mikro) Di PT. Pegadaian (persero) Syariah Lubuklinggau. 
Dalam Akad Pembiayaan Arrum pihak rahin dianggap telah cakap hukum yaitu perkataan dan perbuatannya dapat dipertanggungjawabkan dan sah secara hukum. Rahin ataupun murtahin keduanya dewasa, barang yang dijadikan jaminan pembiayaan halal dan ada shigat akad diantara mereka. Shigat akad selain secara lisan juga tertulis. Dan hal ini tentunya membuat akad berlaku diantara keduanya dan kuat dihadapan hukum.

Menurut Az-Zarqa menyatakan bahwa dalam pandangan syar'a, suatu akad merupakan ikatan secara hukum yang dilakukan oleh dua atau beberapa pihak yang sama-sama berkeinginan untuk mengikatkan diri. Kehendak atau keinginan pihak-pihak yang mengikatkan diri itu sifatnya tersembunyi dalam hati. Oleh sebab itu, untuk menyatakan kehendak masing-masing harus di ungkapkan dalam suatu pernyataan. Pernyataan pihak-pihak yang berakad itu disebut ijab dan qabul. Ijab adalah pernyataan pertama yang dikemukakan oleh salah satu pihak, yang mengandung keinginannya secara pasti untuk mengikat diri. Sedangkan, qabul adalah pernyataan pihak lain setelah ijab yang menunjukkan persetujuannya untuk mengikatkan diri. ${ }^{16}$

Pihak Pegadaian Syariah mengharapkan (murtahin) agar nasabah yang berkeinginan bertransaksi Pembiayaan Arrum ini agar memahami setiap isi perjanjian atau ketentuan-ketentuan pembiayaan yang tercantum dalam Akad Pembiayaan Arrum. Hal ini dimaksudkan agar rahin mengetahui dan memahami perjanjian akad pembiayaan berikut ketentuan-ketentuan didalamnya yang harus ditaati. Jika setelah memahami akad tersebut beserta ketentuan-ketentuannya maka nasabah diharapkan dapat memperhatikan segala yang terdapat dalam perjanjian atau akad pembiayaan.

Namun pada prakteknya nasabah (rahin) tidak sepenuhnya membaca dan mengerti isi Akad Pembiayaan Arrum itu, hal ini dikarenakan sebagian nasabah berlatar belakang pendidikan rendah seperti tidak bisa membaca, menulis sehingga nasabah ada yang tidak mengetahui isi akad itu walaupun sudah menandatangani isi akad tersebut. Tetapi ada juga yang membaca dan memahami akad tersebut sebelum menandatangani akad. Pada dasarnya semua nasabah

${ }^{16}$ Muhammad Syakir Sula, Asuransi Syariah (Life and General)..., h. 39. 
diarahkan oleh petugas untuk membaca secara keseluruhan isi akad atau perjanjian Pembiayaan Arrum.

Pada Pembiayaan Arrum Pegadaian Syariah melakukan transaksi dengan nasabah, kedua pihak ini membuat transaksi Pembiayaan dengan menggunakan akad syariah yaitu akad rahn dan akad ijarah dalam bentuk perjanjian pembiayaan.

Rahn adalah menahan salah satu harta milik si peminjam sebagai jaminan atas pinjaman yang diterimanya. Barang yang ditahan tersebut memiliki nilai ekonomis. Dengan demikian, pihak yang menahan memperoleh jaminan untuk dapat mengambil kembali seluruh atau sebagian piutangnya. Secara sederhana dapat dijelaskan bahwa rahn adalah semacam jaminan utang atau gadai. ${ }^{17}$ Sedangkan Ijarah adalah sewa-menyewa atau akad pemindahan hak guna (manfaat) atas suatu barang atau jasa dalam waktu tertentu melalui pembayaran sewa atau upah tanpa diikuti pemindahan kepemilikan barang itu sendiri. ${ }^{18}$

Dalam Pembuatan Akad Pembiayaan, Selanjutnya Pihak Pegadaian Syariah Sebagai pihak I dan Rahin sebagai pihak II mengadakan perjanjian transaksi yang dicantumkan dalam Akad Pembiyaan Arrum. Dalam akad bahwa Pihak I dan Pihak II telah setuju dengan segala syarat-syarat dan ketentuan yang diajukan oleh Pihak I kepada pihak II. Pihak I menyatakan dengan syarat bahwa pemberian pembiayaan diberikan dengan sejumlah tertentu, sehingga dengan jumlah tersebut Pihak II menggunakannya dengan tujuan Tambahan Modal Usaha yang dilakukan oleh Pihak II. Selama pemberian pembiayaan Pihak II dibatasi waktu untuk proses pelunasan yang terhitung saat penandatanganan akad sampai tanggal berakhirnya akad yang sebelumnya sudah di minta oleh Pihak II pada Pihak I untuk selama waktu tertentu sampai tanggal jatoh tempo.

Dalam Akad Pembiayaan Pihak I menyatakan kepada pihak II untuk menentukan biaya tarif Ijaroh yang diberikan selama pembiayaan berlangsung yang mana besarnya telah tercantum pada Akad Pembiayaan Arrum, yang mana dalam pembayaran Ijaroh ini Pihak II membayarnya bersamaan dengan

\footnotetext{
${ }^{17}$ Muhammad Syafi'I Antonio, Bank Syariah dari Teor.., h. 128.

${ }^{18}$ Muhammad Syafi'I Antonio, Bank Syariah...,h. 117.
} 
pembayaran angsuran pokok pembiayaan yang ditambah Ijaroh. Jika selama proses pembiayaan berlangsung Pihak II membayar angsuran atau pelunasannya sebelum tanggal jatoh tempo atau pembayaran sekaligus maka Pihak I akan mendapatkan potongan atau diskon Ijaroh yang besarnya ditetapkan oleh Pihak II.

Selain itu pada Akad Pembiayaan Arrum selain wajib membayar Ijaroh Pihak I juga menetapkan biaya-biaya yang wajib dipenuhi Pihak II yaitu berupa Biaya Administrasi yang dikenakan dan dipotong pada saat diawal penandatanganan Akad Pembiayaan setelah ditandatanganinya bukti Penerimaan Uang dari pihak I. Dalam Akad pula Pihak I mengenakan adanya Ta'widh (ganti rugi) apabila dalam pembiayaan berlangsung Pihak II mengalami keterlambatan dalam pembayaran angsuran atau pinjaman dengan adanya Ta'widh Pihak I berharap pada Pihak II untuk selalu memperhatikan tanggal jatoh tempo pembiayaan, sehingga Pihak I selalu tepat waktu dalam pembayaran angsuran. Pihak I juga mengenakan segala biaya-biaya BPKB, pembuatan akta Fidusia dan biaya Eksekusi terhadap marhun jika terjadi penjualan barang dalam proses pelunasan pinjaman.

Penyebutan Pihak dalam akad diatas adalah sesuai dengan rukun dan syarat dalam akad, yaitu (a) adanya akid (orang yag berakad), (b) maequd Alaih ialah (sesuatu yang diakadkan) ma'qud alaih atau mahallul aqdi adalh benda yang menjadikan objek akad, (c) maudhu'eal aqd ialah tujuan akad atau maksud pokok mengadakan akad, dan (d) shigat al ,aqd ialah ijab dan kabul.

Adapun syarat-syarat yang terkait dalam mengadaan Akad Pembiayaan Arrum ini adalah:

a. Yang berkaitan dengan pihak-pihak yang berakad. Bahwa Rahin atau Pihak II sebagai pemohon pengajuan pembiayaan datang dengan pengajuan Pembiayaan kepada Pihak I yaitu Pegadaian Syariah yang pada dasarnya berusia diatas 21 tahun dan dianggap cakap bertindak hukum dan berperan langsung dalam proses pemenuhan syarat pengajuan pembiayaan sampai akhirnya disetujui dan menerima Pinjaman.

b. Syarat yang berkaitan dengan Objek Pembiayaan atau jaminan barang yang di jadikan jaminan atas pembiayaan, Yaitu berupa satu unit sepeda motor atau mobil yang mana dapat diketahui jumlah atau nilai pinjaman yang akan 
didapat oleh rahin dari Pegadaian Syariah, beserta biaya-biaya yang akan ditanggung dan tarif ijaroh yang dikenakan oleh pihak I dalam menentukan keuntungan yang diperoleh Pegadaian Syariah. Pada umumnya Rahin menerima persyaratan tersebut, sehingga dengan persetujuan ini terpenuhinya syarat akad.

c. Syarat yang berkaitan dengan iijab kabul, sebelum penandatanganan Akad Pembiayaan Arrum, Rahin dipersilahkan untuk membaca akad yang dibuat tersebut pada umumnya Rahin setelah membaca tidak keberatan dengan isi akad dan Kemudian menandatangani akad tersebut,bahwa bentuk akad pembiayaan ini telah mengikat dan menimbulkan kewajiban diantara keduanya.

Pada prinsip akad, Ijab dan qabul harus dengan cara yang benar-benar niat dari pihak rahin karena asas akad dalam Islam adalah asas al-ridha yaitu asas mengatur bahwa segala transaksi yang dilakukan atas dasar kerelaan dari masingmasing pihak. Ijab dan qabul, tidak hanya berbentuk ucapan (lisan) tetapi bisa dengan Kitabah, Isyarah, perbuatan dan ta'athi (beri memberi).

Dari uraian-uraian tersebut di atas maka dapat difahami, bahwa akad sebagi perbuatan hukum. Setiap akad adalah tindakan hukum, tetapi setiap tindakan hukum tidak dapat disebut sebagai akad. Dari uraian tersebut bila dikaitkan dengan Akad Pembiayaan Arrum sebagaimana di atas syarat sahnya akad bila memenuhi 4 syarat, dapat di jelaskan sebagai berikut:

a. Syarat Kesepakatan, Akad-akad tersebut semuanya telah ditandatangani kedua belah pihak, dengan demikian kedua belah pihak dinilai telah sepakat. Cara menyampaikan sepakat ada beberapa cara yakni dengan cara tertulis, dengan cara lisan, dengan simbol-simbol tertentu bahkan dengan berdiam diri. Cara penandatanganan oleh kedua belah pihak yang berakad di Pegadaian Syariah tersebut memang sudah benar, dan dibuat dihadapan notaris yang mempunyai hukum yang kuat.

b. Syarat kecakapan untuk membuat suatu perikatan atau akad. Pihak-pihak yang mengadakan akad semuanya telah berusia 21 tahun, telah dewasa, cakap 
bertindak Hukum, dengan demikian pihak-pihak yang berakad tersebut telah memenuhi syarat kecakapan.

c. Syarat dengan sesuatu hal tertentu, Barang yang menjadi obyek akad pembiayaan pada saat akad dilaksanakan berwujud surat-surat bukti kepemilikan kenderaan bermotor atau BPKB, yang didalamnya dapat dipastikannya pemilik atas barang, dan Pihak Pegadaiaan Syariah mempercayakan keberadaan Marhun pada nasabah agar digunakan dan dipelihara semestinya.

d. Syarat suatu sebab yang halal, Bahwa Akad Pembiayaan yang mana isi akad atau perjanjian tidak bertentangan dengan undang-undang. Dari uraian-uraian tersebut di atas bahwa syarat sahnya akad-akad terhadap hukum Islam.

\section{F. Kesimpulan}

Berdasarkan hasil penelitian di atas mengenai Analisis Penerapan Multi Akad pada Pembiayaan ARRUM (Ar-Rahn Untuk Usaha Mikro) Di PT. Pegadaian (persero) Syariah Cabang Taba Cemekeh Kota Lubuklinggau , maka penulis dapat mengambil kesimpulan sebagai berikut:

Adapun mekanisme operasional Pembiayaan Arrum pada Kantor Cabang Pegadaian Syariah Kota Lubuklinggau yaitu, Pertama, pihak Pegadaian menerima berkas pengajuan pembiayaan Arrum dari nasabah kemudian mengisi formulir aplikasi pembiayaan Arrum. Kedua, Petugas Pegadaian memeriksa keabsahan dokumen-dokumen yang dilampirkan oleh nasabah dan melakukan survei analisis kelayakan usaha serta menaksir agunan. Setelah memenuhi syarat-syarat yang diajukan oleh pihak Pegadaian, selanjutnya nasabah menandatangani akad pembiayaan Arrum yang diketahui suami atau istri. Ketiga, pencairan dana pembiayaan Arrum cair setelah menandatangani akad pembiayaan.

Dari pembahasan di atas dapat diambil kesimpulan bahwa transaksi multi akad pada dasarnya berkaitan erat dengan syarat dan akad yang disertakan di dalam transaksi tersebut, maka kesahihan setiap transaksi multi akad akan bergantung pada sahih tidaknya syarat dan akad yang disertakan dengannya. Jika syarat dan akad yang ada di dalam transaksi itu sah secara syariat maka transaksi 
multi akad tersebut dapat dikatakan sah secara syariat, namun jika syarat dan akad yang terdapat di dalamnya itu tidak sah secara syariat maka transaksi itu pun tidak bisa dikatakan sah.

Kaidah "hukum asal dalam perkara muamalah adalah kebolehan sampai ada dalil yang mengharamkannya" telah memberikan ruang yang sangat luas bagi perkembangan bentuk akad pada transaksi modern, sesuai dengan ruh syariat Islam yang mampu untuk beradaptasi dan diterapkan di berbagai tempat dalam berbagai keadaan, shalih li kulli zaman wa makan. Namun tetap saja syariat memiliki batasan-batasan yang perlu untuk diperhatikan agar transaksi yang dilakukan sesuai dengan syariat. Pembatasan yang diberikan oleh Syariat dalam berbagai jenis akad itu berkisar pada hal-hal yang diharamkan, jika ada hal-hal yang diharamkan seperti: riba, penipuan, ketidakjelasan, maka transaksi itu akan menjadi haram, namun jika tidak ada unsur haram di dalam transaksi tersebut maka hukumnya akan kembali kepada hukum asal yaitu boleh.

\section{Daftar Pusaka}

Ahmadi Rulam, Metodologi Penelitian Kualitatif, (Yogyakarta: AR-RUZZ MEDIA, 2014)

Ali Zainudin, Hukum Gadai Syariah, (Jakarta: Sinar Grafika,2016)

Alwi Hasan, Kamus Besar Bahasa Indonesia, (Jakarta: Balai Pustaka, 1919)

Antonio Muhammad Syafi'I, Bank Syariah dari Teori ke Praktek, (Jakarta: Gema Insani Press, 2001)

Azzam Abdul Aziz Muhammad, Fiqh Muamalat Sistem Transaksi dalam Fiqh Islam, (Jakarta: Amzah, 2010)

Brosur, PT. Pegadaian (persero) Syariah Taba Cemekeh Kota Lubuklinggau, 2018

Dewi Gemala dkk, Hukum Perikatan Islam di Indonesia, (Jakarta: Kencana, 2005)

Dokumentasi Profil Pegadaian Syariah Taba Cemekeh Kota Lubuklinggau Tahun 2018

Dokumentasi Budaya Perusahaan Pegadaian Syariah Tahun 2018 
Faisal Sanapiah, Format-Format Penelitan Sosial, (Jakarta: PT Raja Grafindo Persada, 1995)

Hadi Amirudin dan Haryono, Metodologi Penelitian Pendidikan, (Jakarta: Pustaka Setia, 1998)

Hafdah Zakiyatul ,"Pengaruh Penyaluran Ar-Rahn terhadap Peningkatan Pendapatan Pegadaian Syariah Cabang Solo Baru Sukoharjo", Skripsi Ekonomi Syariah, (Pekalongan: Perpustakaan STAIN Pekalongan, 2010)

Iskandar, Metodelogi Penelitian Pendidikan dan Sosial Kuantitatif dan Kualitatif, (Jakarta: Gaung Persada Press, 2008)

Kasmir, Bank dan Lembaga Keuangan Lainnya, (Jakarta: Rajawali Press, 2010)

Kasmir, Bank dan Lembaga Keuangan Lainnya, (Jakarta: PT. Raja Grafindo Persada, 2008)

Latumaerissa Julius R, Bank dan Lembaga Keuangan Lain, (Jakarta: Salemba Empat, 2011)

Muhammad, Manajemen Pembiayaan Bank Syariah, (Yogyakarta: UPP AMP YKPN, 2005)

Noor Juliansyah, Metodologi Penelitian: Skripsi, Tesis, Disertasi, dan Karya Ilmiah Ed. 1 Cet. 1, (Jakarta: Kencana Prenada Media Group, 2011)

Putra Nusa, Penelitian Kualitatif: Proses dan Aplikasi (Jakarta: Indeks, 2011)

SalehMuhammad dan Ikit, Pengantar Bank Syariah, (Lubuklinggau: Pustaka Al-Azhaar, 2014)

Salman Kautsar Riza, Akuntansi Perbankan Syariah Berbasis PSAK Syariah, (Padang: Akademia Permata, 2012)

Silalahi Ulber, Metode Penelitian Sosial, (Bandung: PT Refika Aditama, 2009)

Soemitra Andri, MA, Bank dan Lembaga Keuangan Syariah (Jakarta: Kencana, 2010)

Soeratno dan Lincolin Arsyad, Metodologi Penelitian untuk Ekonomi dan Bisnis, (Yogyakarta: UPP STIM YKPN, 1988) 
Soviana Millatina," Pengaruh Pembiayaan Ar-Rum (ar-rahn untuk usaha mikro kecil) terhadap perkembangan usaha Pegadaian Syariah Cabang Solo Baru Sukoharjo", Skripsi Ekonomi Syariah , (Pekalongan: Perpustakaan STAIN Pekalongan, 2010)

Sula Muhammad Syakir, Asuransi Syariah (Life and General): Konsep dan Sistem Operasional, (Jakarta: Gema Insani Press, 2004)

Susilo Edi, Analisis Pembiayaan dan Risiko Perbankan Syariah, (Yogyakarta: Pustaka Pelajar Press, 2017)

Sutedi Adrian, Hukum Gadai Syariah, (Bandung: Alfabeta, 2011)

Sutrisnohadi, Metodologi Research, (Yogyakarta: Yayasan Penerbit Fakultas psikologi, 1990)

Utomo Budi, “Analisis Prosedur dan Penyelesaian Pembiayaan Bermasalah pada Produk Gadai Emas di Bank Syariah Mandiri Cabang Pekalongan”, Tugas Akhir Perbankan Syariah, (Pekalongan: Perpustakaan STAIN Pekalongan, 2015).

Wangsawidjaja, Pembiayaan Bank Syariah, (Jakarta: PT. Gramedia Pustaka utama, 2010)

Wawancara, Ahmad Wasik, Teller Unit Pegadaian Syariah Taba Cemekeh Lubuklinggau, 3 Mei 2018

Wawancara, M. Firdaus, Manager dan Penaksir Unit PT. Pegadaian (persero) Syariah Taba Cemekeh Lubuklinggau, 3 Mei 2018.

Wirawan, EVALUASI: Teori, Model, Standar, Aplikasi, dan Profesi, (Jakarta: PT Raja Grafindo Persada, 2011)

www.pegadaian.co.id 